\title{
The Russian-Mongolian vector of the eastern energy strategy of Russia: role of energy potential of the Baikal region
}

\author{
Boris Saneev ${ }^{*}, 1$, Irina Ivanova $^{1}$, Alexander Izbuldin ${ }^{1}$, Svetlana Muzychuk ${ }^{1}$, Elena \\ Maysyuk $^{1}$, Gennady Borisov², and Sodovin Butkhuyag ${ }^{3}$ \\ ${ }^{1}$ Melentiev Energy Systems Institute of Siberian Branch of the Russian Academy of Sciences, 130, \\ Lermontov str., Irkutsk, 664033, Russia \\ ${ }^{2}$ Department of Regional Economic Research BSC SB RAS, Ulan-Ude, Russia \\ ${ }^{3}$ Mongolian State University of Science \& Technology, Ulan-Bator, Mongolia
}

\begin{abstract}
The paper is concerned with the specific features of Russia's economic development in a new economic environment that caused the need to revise the priorities of energy policy. The research presents the initial conditions, targets and strategic directions of energy development in the East of the country. The focus is made on the priority lines of innovation and technology cooperation between Russia and Northeast Asian countries in the field of energy, and recommendations on necessary conditions and initiatives for their successful implementation are given.
\end{abstract}

Keywords: power export, gas main, consumer gasification, supplies of oil products, inter-country power system, renewable energy sources.

\section{Introduction}

The national interests of Russia require intensification of the mutually beneficial cooperation with the countries of Northeast Asia. Great significance in the entry of the Russian energy resources to the markets of Mongolia, Japan, China and Korea is attached to East Siberia and the Far East. Among the eastern regions of the Russian Federation, the Baikal region including the Irkutsk Region, the Republic of Buryatia, and Transbaikal Territory occupies a special place for Russia to enter the dynamically developing market of Mongolia and is an outpost in the implementation of the mutually beneficial energy cooperation between the two countries.

The role of NEA countries in the world economy is increasing, and therefore, this region is getting more significant as a contact zone of Russia with Mongolia and China. Furthermore, since some ports in the Black and Baltic seas were lost for Russia, the role of transportation infrastructure of the region in the performance of its transit functions in order to service the domestic and international economic and energy relations is increasing

\footnotetext{
*Corresponding author: saneev@isem.irk.ru
} 


\section{Current state and potential of energy industries in the region}

A large fuel and energy basis of the country is established in the Baikal region. In 2015 it produced more than 34 million t of coal, generated about 62 billion kWh of electricity, and refined 9.1 million $t$ of oil. Hydropower plants of the Baikal region generated nearly $17 \%$ of all electric power in the Siberian Federal District [1].

The energy sector of the Baikal region makes a pronounced contribution to production indices of the country. In 2015 its enterprises produced $9.2 \%$ of Russian coal, generated $5.8 \%$ of electricity, refined $3.2 \%$ of crude oil and $3 \%$ of oil. The regional energy sector covers basically demands of the own economy for energy resources. In 2015 its share in consumed coal in the country was $12.1 \%$, electricity $-6.2 \%$, thermal energy $-4.3 \%$, oil products $-3.9 \%$ [1].

Coal industry is of great importance for the economy of the Baikal region as it supplies fuel to the enterprises of electric power and heat power industries, production facilities, and population. Coal is the major fuel in the region.

Geological resources of coal in the territory of the region make up 28.9 billion $\mathrm{t}$ ( $32 \%$ of national), balance reserves -29.5 billion $t$ as of 01.01 .2015 [6]. Moreover, $87 \%$ of the total reserves are concentrated in the deposits with favorable development conditions. This allows open-cast mining, which is the most effective way of coal production.

Electric power industry of the Baikal region is a key industry. It is represented by 36 thermal and hydro power plants. The installed capacity of the power plants in the Baikal region makes up nearly $16.5 \mathrm{GW}$, of which $55 \%$ falls on hydro power plants (above $9 \mathrm{GW}$ ). Four hydro power plants that operate in the region produce above $58 \%$ of electricity. Moreover, the region has nearly 500 diesel power plants with a total capacity of $420 \mathrm{MW}$, which are used as backup and autonomous energy sources [1].

Heat in the region is produced by thermal power plants, numerous boiler plants, heat utilization plants and electric boiler plants.

The level of gas use in the Baikal region is extremely low - nearly 5\%, whereas for Russia on average it is above $66.2 \%$, and in the western regions of the country even higher [3]. At the same time the explored and prepared gas reserves are sufficient to begin the commercial development of the fields and convert consumers to gas.

The Baikal region has unique reserves of hydrocarbon resources, which are mainly concentrated in the territory of the Irkutsk Region. As of 01.01.2015 the state balance registered 37 fields of hydrocarbon fuel with a total recoverable reserves of: oil -907.2 million $\mathrm{t}$, natural gas -4.7 trillion $\mathrm{m}^{3}$, condensate -182.2 million $\mathrm{t}$ in the region $[4,5]$. The field unique in reserves (categories $\mathrm{C}_{1}+\mathrm{C}_{2}$ about 2.5 trillion $\mathrm{m}^{3}$ ) is Kovykta gas and condensate field. There is also Levoberezhnoe field, Angaro-Lenskoe, Chikanskoe, Bratskoye and other fields.

Oil production in the Irkutsk oblast reached 15.8 million $t$ in 2015 that is supplied to the oil pipeline system "East Siberia - Pacific ocean" (ESPO) basically for export. Natural gas production increased to 2.2 billion $\mathrm{m}^{3}$ in 2015 . However, it is used extremely inefficiently, mainly it is burnt at flare units, and pumped back into the reservoir [5]. Only insignificant part of the gas produced is consumed for auxiliary needs of the gas producer facilities.

Oil refining in the territory of the Baikal region is performed by the Angarsk Petrochemical Company with a refining capacity of 10.2 million $t$ of crude oil a year. Owing to a considerable share of secondary processes, the Angarsk oil refinery is characterized by a higher oil refining ratio - $76.5 \%$. In 2015 the company refined 9.1 million t of oil, produced 8.11 million $\mathrm{t}$ of marketable product [6]. 
The Angarsk oil refinery plays an important part in supply of oil products to the consumers in Siberia and the Far East. The refinery practically completely provides consumers in Baikal region. Moreover, its products are sold outside the region and are exported to 14 countries of the world: China, Mongolia and other NEA countries. The share of export in the total amount of supplies makes up $26 \%$.

The territory of the Baikal region is characterized by a considerable potential of renewable natural energy resources. There is $37 \%$ of hydro energy, $43 \%$ of solar energy, $30 \%$ of wind energy and more than $50 \%$ of wood biomass potential in East Siberia. The most favorable conditions for the use of solar potential for energy purposes are in the southern areas of the region and those of wind potential - in the depression of Lake Baikal (Fig.1) [7].

a)

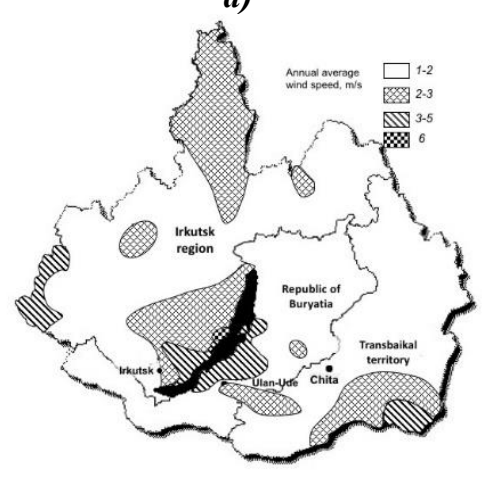

b)

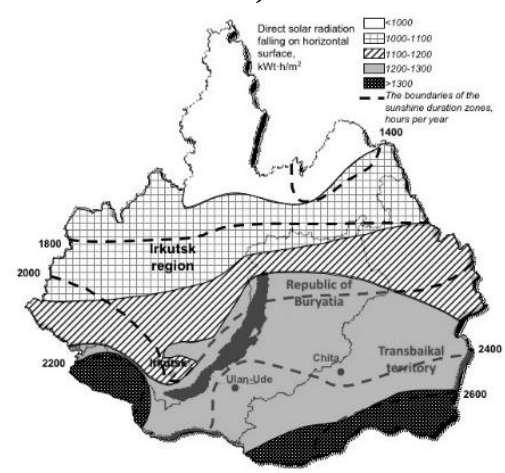

Fig. 1. Zoning of the Baikal region territory by the indices: a) wind potential, b) solar potential.

\section{State and strategic directions for the bilateral energy cooperation}

Currently Russia is ranked third in the amount of Mongolia's export and first in the amount of its import. And more than half the Russian-Mongolian commodity turnover falls on the Irkutsk oblast [8]. Today the key part in the development of mining industry of Mongolia is played by the Mongolian-Russian company "Erdenet". Russia annually supplies to Mongolia 140-150 million kWh of electric energy, and 560-580 thousand t of oil products. Russian oil products provide for $92 \%$ of Mongolia's demand. In 1999 Russia started to supply liquefied natural gas.

In the Declaration on development of the strategic partnership between the two countries the arrangements were reached on development of cooperation in different fields, including the improvement of transportation infrastructure, joined development of mineral deposits, production of uranium, modernization of joint ventures: Erdenet Mining Corporation, Mongolrostsvetmet LLC and JSC "Ulan Bator Railway", and development of cross border interaction.

The focal issue of the cross border cooperation is the creation of a special economic zone in the area of the towns Kyakhta and Altanbulag as well as the development of infrastructure and engineering communications, first of all railway and automobile roads.

The prospects for the cooperation between the two countries in the energy field are related to the implementation of strategic priorities in the development of oil industry, gas industry, coal industry, power industry and renewable energy.

An important aspect of oil and gas cooperation between the two countries is expansion and specification of the resource base, related to the geological surveys to be conducted, increase in the proved reserves, additional exploration and discovery of hydrocarbon fields in the territory of Mongolia. 
The Mongolian party is interested in further increase in the supplies of oil products to Mongolia's market by the Russian companies to 1.5 million $t$ In this context, there are intentions to extend acting contracts concluded with the JSC "NK Rosneft". Currently there is an interest of the JSC "NK Rosneft" in further strengthening of energy cooperation and supply of oil products to the small-scale wholesale and retail segments of Mongolia's market through the creation of a network of refueling stations.

Taking into account the construction of the Darkhan oil refinery in Mongolia, it is necessary to consider the possibility of supplying oil either by oil pipeline system to be constructed, or by railway.

Prospective oil and gas cooperation between Russia and Mongolia is also related to the possibility of creating a joint venture on production and mutually beneficial distribution of products. The parties support the idea of stable supplies of liquefied hydrocarbon gas from Russia to Mongolia on mutually beneficial terms.

Furthermore, there are preconditions for supply of network gas to consumers in the Baikal region and Mongolia in the event that the export gas pipeline "Russia-China" is constructed in their territory. Based on the available estimates [9], large gas consumers are concentrated in the cities of Sukhe-Bator, Darkhan and Ulan-Bator. Their annual demand for natural gas is estimated at $0.4-0.6$ billion $\mathrm{m}^{3}$.

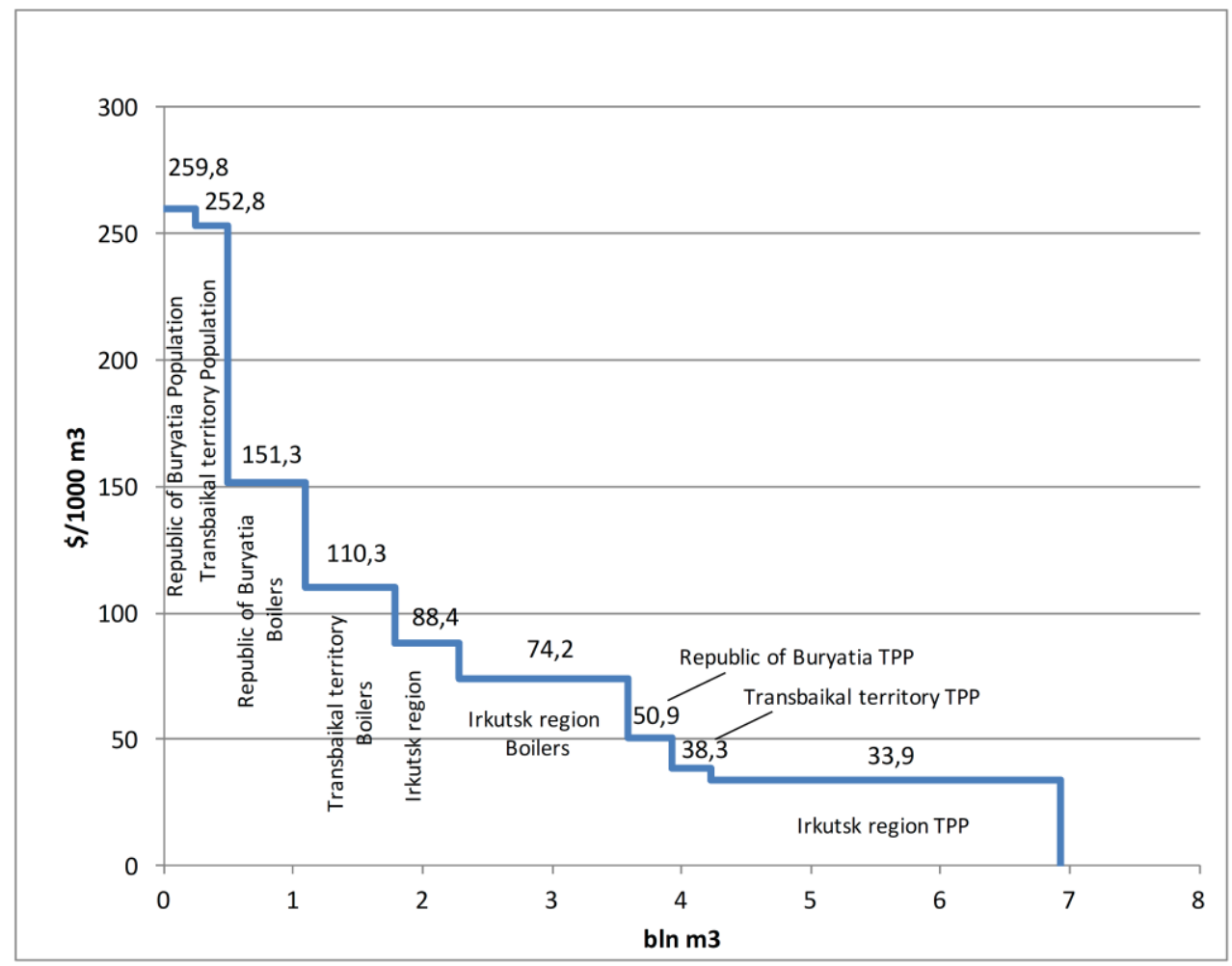

Notes. Initial data for calculations: Dollar exchange rate $-60 \mathrm{RUB} /$ doll.

Fig. 2. Competitive prices of natural gas and potential gas demand for the population, boilers and thermal power plants of the Baikal region. 
Since there is interfuel competition in different categories of consumers, the maximum demand for gas in the region is estimated at 7-8 billion $\mathrm{m}^{3}$ by 2030, including: 4-4.5 - Irkutsk Region; 1.0-1.5 - Republic of Buryatia; 1.0-1.5 billion $\mathrm{m}^{3}$ - Transbaikal Territory (Fig.2) [10]. The Table presents initial indices to determine competitive natural gas prices for thermal power plants, boiler plants, and population of the RF entities located in the Baikal region.

Table. Cost indices as of July 2017

\begin{tabular}{|l|c|c|c|}
\hline \multirow{2}{*}{} & \begin{tabular}{c} 
Electricity prices for \\
population, \\
\cline { 3 - 4 }
\end{tabular} & \multicolumn{2}{|c|}{ Coal prices, RUB/t } \\
\cline { 3 - 4 } & $\mathrm{RUB} / \mathrm{kW} \cdot \mathrm{h}$ & Boilers & Thermal power plants \\
\hline Transbaikal Territory & 2.89 & 1595 & 1131 \\
\hline Republic of Buryatia & 2.97 & 2187 & 1500 \\
\hline Irkutsk Region & 1.01 & 1073 & 588 \\
\hline
\end{tabular}

Construction of a special gas pipeline system for supplying gas to consumers in the Republic of Buryatia, Transbaikal Territory and Mongolia with an annual gas consumption of 1.7-2.1 billion $\mathrm{m}^{3}$ is commercially inefficient. This variant can be implemented only in the case of financial support from Russia and Mongolia. The supply of Irkutsk natural gas to Mongolia is cost-effective only if there is a large-diameter main export gas pipeline laid in these territories [11].

In the coal industry Russia and Mongolia can cooperate in the project for the development of the world's largest Tavantolgoi coking coal deposit.

Among the main directions in the cooperation between Russia and Mongolia in this field are the development of infrastructure and engineering communications, first of all railways, which make it possible to connect coal producers to consumers, and supply up-to-date mining equipment. Russian JSC "INTER RAO UES" is ready to take part in the construction of an infrastructural thermal power plant on the deposit.

Construction of a railway 1.1 thousand $\mathrm{km}$ long from the Tavantolgoi deposit to Russia's border is one of the options for development of the transport corridors for possible export of its coking coke to the market of the NEA countries [12]. JSC "Russian Railways" is willing to participate in the project and thereby combine construction of the railway with the development of Mongolian mineral resources, which will substantially increase coal transportation by rail.

The cooperation in electric power industry is connected to two directions: construction and reconstruction of power plants and creation of an interstate power system.

One of the problems in the Mongolian energy sector is the shortage of peak electric and thermal power during winter peak loads in Ulan-Bator. This problem can be solved by implementing different energy projects [13]. For instance, the construction of a peak thermal power plant in the east of Ulan-Bator that will run on gas fuel exported from Russia.

At the 20th meeting of the Russian-Mongolian Intergovernmental Commission on TradeEconomic and Scientific-Technological Cooperation the Russian party informed the Mongolian party of the technical capability of increasing electricity supplies from Russia to Mongolia and expressed interest in their augmentation [14].

The Russian party informed the Mongolian party of the interest of JSC "EuroSibEnergo" to develop the cooperation with Mongolian companies in the electric power sphere, in particular in establishment of joint enterprises, performance of special construction and erection and commissioning works at power plants in the territory of Mongolia, delivery of electric power equipment, performance of work and provision of consulting services on the power quality analysis and control, staff training and its professional advancement.

One of the promising directions in the cooperation between Russia and Mongolia (and other NEA countries) is the project intended for the creation of an interstate electric power system, which implies the development of electric ties between the eastern regions of Russia 
and neighboring NEA countries. The cross-border transmission lines constructed for this purpose can be used both to export electricity from Russia and to integrate electric power systems in the indicated countries for their joint (or simultaneous) operation and formation of common electricity and capacity markets [15].

At present, the interstate electric ties between Russia and Mongolia are represented by two transmission lines: a $220 \mathrm{kV}$ transmission line from the Gusinoozerskaya condensing power plant to Darkhan and a $110 \mathrm{kV}$ transmission line from the Kharanorskaya condensing power plant to Choibalsan. Further increase in electricity export will inevitably require both installation of suitable transmission lines, and commissioning of additional generating capacities.

The implementation of this scheme helps solve power supply reliability problems in a number of entities of the Russian Federation and opens up a possibility of parallel operation of IPS of Siberia and IPS of East, and electricity export to Mongolia and China.

The need for such an interstate interconnection is also recognized by the Mongolian party, since it is supposed that in the nearest future almost all power systems in Mongolia will experience power shortage of $400 \mathrm{MW}$ in total.

According to the Memorandum between the Ministry of Energy of the Russian Federation and the Ministry of Energy and Mineral Resources of Mongolia dated October 14, 2010, the relevant departments provide necessary assistance to the companies of both countries in electric power cooperation to enable parallel operation of the Western power system of Mongolia and the power system of Russia.

Implementation of "The program for creation of an economic corridor Russia-MongoliaChina" signed at the 3rd meeting of the heads of the states dated 23.06.2016 in Tashkent makes an essential contribution to development of the Russian-Mongolian cooperation, in particular in the energy sphere. The program comprises 32 projects of cooperation and only one energy project. The following projects can be considered as potential: construction of the gas pipeline "Irkutsk - Ulan-Ude - Ulan-Bator - China (on the basis of the Kovykta field), construction of the $500 \mathrm{kV}$ transmission line "Gusinoozersk - Ulan-Bator, construction of the Mokskaya HPP on the Vitim river and the Ust-Kutskaya TPP on the associated gas of the fields in the North of the Irkutsk oblast [16].

The promising direction in cooperation between Russia and Mongolia is improvement of energy effectiveness and development of renewable energy. The Mongolian part expressed its interest in this area at the 20th Meeting of the Russian-Mongolian Intergovernmental Commission on Trade-Economic and Scientific-Technological Cooperation and proposed consideration of the possibility for exchanging experience in solving these problems [14]. Recently the issues of renewable energy development in Mongolia have been devoted much attention, sets of projects on construction of solar, wind and hydro power plants have been under consideration [17].

Participation of the Russian specialists in the development and feasibility studies of joint projects for construction of small-scale hydro power plants could be one of the directions of cooperation in this sphere. The experience and knowledge of the Russian specialists will make it possible to ensure delivery of equipment for small-scale hydro power plants and provide professional training in its maintenance for the staff. An important joint project within this direction is the construction of renewable energy plants in the Baikal-Khubsugul zone in order to mitigate an anthropogenic impact of energy facilities on the environment.

\section{Conclusions}

1. A need has arisen to devise a scientifically grounded strategy for energy cooperation 
between Russia and Mongolia under the conditions of energy integration and collaboration with the NEA countries. The strategy should reflect the order of development of energy resources, show the sequence and stages of energy supply to domestic consumers and energy export, and assess the socioeconomic consequences of the decisions made not only for the companies, but for the regions and countries as well.

2. At present, the main direction of long-term energy cooperation between Russia and Mongolia is determined and the raw material base in both countries is well studied $[18,19]$.

3. More attention should be paid to the coordinated measures taken by the participants (countries, regions, companies), i.e. to the economic, legislative, and other initiatives connected to the implementation of large-scale interstate energy projects. Due consideration should be given to the energy pricing formulas.

4. Research and design energy institutes, specialized higher educational institutions, scientific societies, and energy companies in Russia and Mongolia should take an active part in achieving these goals, and make a valuable contribution to solving the problem, which is important both for these two countries and for the whole Northeast Asia.

\section{References}

1. Forms of statistical reporting on the energy sector. M.: Rosstat (2015).

2. State balance of mineral reserves of the Russian Federation. Coal. Volume VII, Siberian Federal District. Part 2. M.: Ministry of natural resources and ecology of RF. (2016), 314 p. (2016) (in Russian)

3. Data of PJSC "Gazprom". Gasification. URL:http://www.gazprom.ru/about/production/gasification/ (in Russian)

4. Data of PJSC "Gazprom". Reserves of the Kovykta gas condensate field. URL:http://www.gazprom.ru/about/production/projects/deposits/kovykta/ (in Russian)

5. State and utilization of mineral resources of the Irkutsk oblast (as of 01.01.2015) URL:http://atlaspacket.vsegei.ru/_Files/пакеты_05_2016/SFO/PDF/IRKUT_OBL/31_ 32_spravka_msb.PDF (in Russian)

6. Data of "NJSC "Rosneft" URL:https://aoanhk.rosneft.ru/about/Glance/OperationalStructure/Pererabotka/aoanhk/ Osnovnie_pokazateli/ (in Russian)

7. Energy sector of the Baikal region: current state, prospects for development / Ed. by B.G.Saneev, Russian Academy of Sciences. Siberian Branch, Melentiev Energy Systems Institute. Novosibirsk: Academic Publishing House "GEO”, 176 p. (2015) (in Russian)

8. Chudanzhiy Sharav. Current state of economic reforms in Mongolia. Izvestiya of Irkutsk State Economics Academy, No. 5 (55), P.110-113 (2007) (in Russian).

9. A long-term Vision of Natural Gas Infrastructure in Northeast Asia, 2005 Year Version. Northeast Asian Gas \& Pipeline Forum, (September 2005), Tokyo, Japan, 94 p.

10. B.G.Saneev, L.A.Platonov, E.P.Maysyuk, A.K.Izhbuldin. Multipurpose utilization of natural gas in the Baikal region: prerequisites, directions, conditions for implementation. Region: economy and sociology, No. 3, P. 190-202. (2012) (in Russian)

11. Eastern vector of Russian energy strategy: current state and future projections / Ed. by N.I. Voropai, B.G. Saneev, Novosibirsk: GEO, 368 p. (2011) (in Russian).

12. Gotov Dugerjav. Enhancing Northeast Asia and Mongolia cooperation through transport network development [Electronic resource]. http://www.kiep.go.kr/include/filedown.jsp?fpath=POOL0206\&NO=185518\&FNO=9 62 (accessed 16.10.2017). 
13. H.Enkhzhargal, S.Batmunkh, V.A.Stennikov. Prospective lines of power system development in Mongolia. Energy policy, Issue 4, P. 70-81. (2012) (in Russian)

14. Minutes of the 20th meeting of the Russian-Mongolian Intergovernmental Commission on Trade-Economic and Scientific-Technological Cooperation dated 13, Ulan-Bator, 20 p. (December, 2016) (in Russian)

15. G.O.Borisov Problems and prospects for energy development of Zabaikalsky krai. Materials of the round-table discussion no. 2 "Development of energy and energy infrastructure as a factor of economic growth in Siberia and the Far East", International Economic Conference "New economy - new approaches", Ulan-Ude (2012), Electronic resource: http://egov-buryatia.ru/index.php?id=4948. (in Russian)

16. G.O.Borisov, Z. B.-D.Dondokov, V.O.Namzhilova. Economic corridor: ChinaMongolia-Russia: wait mode. ECO, No. 5 (515), P.98-106 (2017) (in Russian)

17. National policies for new and renewable energy of the countries in North-East Asia region. Country Reports of the countries in Northeast Asia. Seoul: Korea Energy Economics Institute, P. 15-40. (2016)

18. N.I.Voropai, B.G.Saneev, S.Batkhuyag, Kh.Enkhzhargal. Energy cooperation between Mongolia and Russia: current state and strategic directions (results of the RussianMongolian project of 2011-2012). Spatial Economics, No. 3, P.108-122. (2013) (in Russian).

19. N.I.Voropai, B.G.Saneev, I.Yu.Ivanova, A.D.Sokolov, E.P.Maysyuk, N.M.Sysoeva, G.O.Borosov, S.Batkhuyag, Kh.Enkhzhargal. Forecasting of strategic directions in energy cooperation between Russia and Mongolia. Scientific cooperation of the Siberian Branch of RAS with Mongolia in the first half of the 21st century. Issue 1: 2011-2013. Novosibirsk: Publishing House SB RAS, P.123-140. (2015) (in Russian) 